\title{
AKSJOLOGIA ŹRÓDEŁ PRAWA
}

Akceptacja w nauce prawa założenia racjonalności prawodawcy przesąza o tym, że przyjmuje się, iż podmiot ten w swej działalności konsekwentnie kieruje się nie tylko niesprzeczną i tworzącą system wiedza, ale nadto żywionymi preferencjami, które sa asymetryczne ${ }^{1}$ i przechodnie ${ }^{2}$. Efektem tak kwalifikowanej aktywności staje się „podjęcie [przez prawodawcę- dop. MK] takiej spośród możliwych (w świetle jego wiedzy) czynności, która niezawodnie prowadzi (wedle tej wiedzy) do najwyżej preferowanego stanu rzeczy"3.

Jeżeli więc prawodawcy - jako podmiotowi racjonalnemu - przypisuje się określony system wartości ${ }^{4}$, powstaje zagadnienie, w jaki sposób ów system można zrekonstruować.

$\mathrm{Na}$ najbardziej ogólnym poziomie wydaje się, że termin „wartości prawodawcy” („wartości przypisywane prawodawcy”) obejmuje trzy zbiory.

Pierwszy zbiór tworzą wartości obowiązujące prawnie (wartości prawne). Nie bez powodu status tych wartości ma charakter analogiczny do statusu obowiąujacych norm prawnych. Podobnie jak normy w wyniku aktu stanowienia zyskują kwalifikację obowiązujących prawnie, a tym samym stają się elementem systemu prawa, tak wartości w drodze prawodawczego fiat zyskuja takie samo miano: obowiąujacych prawnie. Wprawdzie polski prawodawca nie korzysta $\mathrm{z}$ technik legislacyjnych wprost wskazujących na określone wartości jako prawne, ale taka redakcja przepisów nie należy do wyjątków, np. $\mathrm{w}$ europejskich konstytucjach ${ }^{5}$, a nadto communis opinio doctorum $\mathrm{w}$ liniach

\footnotetext{
${ }^{1}$ Asymetryczność preferencji oznacza, że jeżeli $X$ preferuje $p$ przed $q$, to nieprawda, że $X$ preferuje $q$ przed $p$.

${ }^{2}$ Przechodniość preferencji oznacza, że jeżeli $X$ preferuje $p$ przed $q$ oraz preferuje $q$ przed $r$, to $X$ preferuje $p$ przed $r$. L. Nowak, Interpretacja prawnicza. Studium $z$ metodologii prawoznawstwa, PWN, Warszawa 1973, s. 39-40.

${ }^{3}$ Ibidem, s. 39.

${ }^{4}$ Por. np.: „,...] współczesną konstytucję powinno się traktować jako zobiektywizowany wyraz pewnego systemu wartości [podkr. - MK] - podstawowych dla funkcjonowania całego państwa i społeczeństwa [...]” (s. 32). „Powszechnie przyjmuje się bowiem w świecie współczesnym, że nie ma konstytucji aksjologicznie neutralnych - każda odzwierciedla pewien system wartości i dzięki temu staje się dokumentem spójnym wewnętrznie" (s. 40) - oba cytaty w: L. Garlicki, Polskie prawo konstytucyjne. Zarys wyktadu, wyd. 15, Liber, Warszawa 2011.

${ }^{5}$ Zob. np. art. 1 ust. 1 Konstytucji Hiszpanii: „Hiszpania konstytuuje się w postaci społecznego i demokratycznego państwa prawnego, które chroni jako najwyższe wartości swego porządku prawnego [podkr. - MK] wolność, sprawiedliwość, równość i pluralizm polityczny”, w: Konstytucja Hiszpanii, tłum. T. Mołdawa, Wyd. Sejmowe, Warszawa 2008, s. 30.
} 
egzegetycznych przede wszystkim konstytucji odtwarza katalogi chronionych przez nią wartości.

Podstawowe źródło dekodowania wartości prawnych stanowią zasady prawa. Kwalifikowane jako normy szczególnie doniosłe dla konstrukcji i funkcjonowania systemu prawa ${ }^{6}$ ujawniają wyraźny zwiąek z aksjologią ${ }^{7}$. Znajduje to swoje odzwierciedlenie albo w stwierdzeniu, że „teoria zasad jest teorią wartości oczyszczoną z nieuzasadnionych założeń”, albo w zajęciu stanowiska, że możliwe jest określenie zasad jako postaci „sformułowania założeń aksjologicznych systemu"9, albo przez podkreślenie, że zasady są wypowiedziami wskazującymi, jak osiagnąć określone wartości ${ }^{10}$, albo w końcu - w przyjęciu, że norma zyskuje charakter zasadniczej ze względu na „oceny celu, zadań, funkcji w danym kontekście funkcjonalnym jej stosowania, to jest głównie ze względu na cele systemu prawa (lub też jego części) w sytuacji społeczno-politycznej stosowania prawa i świetle ocen i reguł społecznych (polityczne, moralne), jakie w tej sytuacji oceniajacy uważał za właściwe"11.

Ta konsekwentna linia argumentacyjna pozwala na definicyjne powiązanie pojęcia zasad prawa $\mathrm{z}$ wartościami. Zasady są takimi obowiąujaccymi normami prawnymi, które nakazują realizowanie określonych wartości ${ }^{12}$. Stąd też można przyjąć, że nazwy uzupełniające termin „zasada” - np. równość w zasadzie równości, ochrona godności człowieka w zasadzie ochrony godności człowieka, państwo prawne w zasadzie państwa prawnego - to nazwy wartości. Wiele wartości będących przedmiotem ochrony zasad już na poziomie językowego kształtu ujawnia swój charakter. Równość, godność człowieka, wolność czy sprawiedliwość społeczna to niewątpliwie źródłowo wartości moralne. Wprowadzone do systemu prawnego poprzez ich konstytucjonalizację stały się tym samym wartościami prawnymi. Ale prawodawca czyni wartościami prawnymi stany rzeczy (obiekty, zachowania, stosunki), jakie wcześniej nie posiadały statusu aksjologicznego. Zasada państwa prawnego, zasada nieretroakcji, zasada demokracji przedstawicielskiej i wiele innych kwalifikuja jako cenne określone układy stosunków społecznych pierwotnie występujące jako pewne wzorce funkcjonowania podmiotów władzy publicznej. Dopiero wyraźna decyzja ustrojodawcy przekształca faktyczne czy wyobrażone stany rzeczy w wartości. To novum w świecie aksjologii powoduje, że z reguły jako nazwa wartości zostaje zachowana nazwa stanu rzeczy - faktu. Wówczas o tym, w którym z dwóch możliwych znaczeń dany termin występuje, przesą-

${ }^{6}$ M. Zieliński, Konstytucyjne zasady prawa, w: J. Trzciński (red.), Charakter $i$ struktura norm konstytucji, Wydawnictwo Sejmowe, Warszawa 1997, s. 59.

7 Szczególnie ujawnia się to w zwrocie kwalifikującym zasadę jako normę „doniosłą aksjologicznie”, w: L. Leszczyński, Stosowanie generalnych klauzul odsyłajacych, Zakamycze, Kraków 2001, s. 111.

${ }^{8}$ R. Alexy, Teoria praw podstawowych, tłum. B. Kwiatkowska, J. Zajadło, Wyd. Sejmowe, Warszawa 2010, s. 32.

9 J. Romul, Wstę do teorii państwa i prawa. Zarys wykładów, WN UAM, Poznań 2001, s. 73.

10 Stanowisko A. Stelmachowskiego. Zob.: S. Wronkowska, Sposoby pojmowania „zasad prawa” (Dyskusja w Komitecie Nauk Prawnych PAN), „Państwo i Prawo” 1972, z. 10, s. 168.

11 J. Wróblewski, Prawo obowiazujace a „ogólne zasady prawa”, Zeszyty Naukowe Uniwersytety Łódzkiego, Nauki Humanistyczno-Społeczne, Seria I, z. 42, Łódź 1965, s. 26.

${ }^{12}$ M. Kordela, Zasady prawa. Studium teoretycznoprawne, WN UAM, Poznań 2012, s. 102. 
dza kontekst jego użycia. Zasada hierarchiczności źródeł prawa jako zasada czyni z hierarchiczności źródeł prawa wartość, uzasadnianą w jej obowiązywaniu prawnym ochroną nadrzędnej roli konstytucji oraz prymatu ustawy w stosunku do aktów pochodzacych od podmiotów władzy wykonawczej. Natomiast samo stwierdzenie o zróżnicowanej mocy prawnej aktów normatywnych ma charakter czysto opisowy i może pełnić funkcje sprawozdania z określonych rozstrzygnięć przyjmowanych przez dany system prawny.

Obok zasad prawa niewątpliwą podstawę do wyprowadzania wiążących wartości prawnych tworzą przepisy regulujące prawa i wolności jednostki. Porządkowana przez naczelną wartość godności człowieka aksjologia praw człowieka zawiera te elementy, na jakie wskazują poszczególne kategorie praw i wolności, np. prawo do ochrony życia prywatnego, prawo do stowarzyszania się, prawo do ochrony zdrowia, wolność sumienia i religii, wolność wypowiedzi, wolność badań naukowych - czynią wartościami prawnymi - odpowiednio: życie prywatne, stowarzyszanie się, ochronę zdrowia, swobodę sumienia i religii, wypowiedzi oraz badań naukowych.

Zgodnie przez naukę prawa wskazywane preambuły - przede wszystkim do konstytucji - jako naturalna dla ujawniania preferencji prawodawcy część aktu normatywnego, jedynie w ograniczonym zakresie pełnią funkcję informująca o tym fragmencie aksjologii prawodawcy, jaką tworzą wartości obowiązujące prawnie. Wstęp do Konstytucji RP z 1997 r. pozwala na argumentację pozytywna w tym zakresie - jakkolwiek nie w każdym przypadku konkluzywna - m.in. w odniesieniu do takich wartości, jak pomocniczość (zasada pomocniczości), współdziałanie władz, dialog społeczny, rzetelność i sprawność w działaniu instytucji publicznych.

Jednakże wartości obowiąujące prawnie nie są jedynym zbiorem należącym do klasy wartości prawodawcy. Druga grupę tworzą wartości, do których prawodawca wyraźnie odsyła poprzez użycie klauzul generalnych czy też zwrotów niedookreślonych ${ }^{13}$. Udzielenie podmiotowi stosującemu prawo, np. sądowi, wyraźnej kompetencji do podjęcia rozstrzygnięcia albo na podstawie pozaprawnych norm mających uzasadnienie aksjologiczne przede wszystkim pod postacią zasad współżycia społecznego, albo poprzez wzięcie pod uwagę wartości, które wiążą się z użyciem takich zwrotów, jak dobra wiara, dobre obyczaje, należyta staranność, czy zwyczaje uczciwego obrotu - powoduje, że powoływane w ten sposób wartości nie stają się wprawdzie wartościami prawnymi w ścisłym tego słowa znaczeniu, ale z całą pewnością współkonstytuuja porządek prawny rozumiany jako „działajacy faktycznie system prawny”14. W ten sposób wartości odesłania wiążą, ale jedynie przez indywidualne i konkretne normy będące efektem aktów stosowania prawa.

Trzeci zbiór wartości objęty działaniem założenia racjonalności aksjologicznej prawodawcy tworzy kategoria tzw. moralności publicznej. Zawiera ona wszystkie te wartości i normy moralne, jakie są podzielane przez większość

${ }^{13}$ Z. Ziembiński, Problemy podstawowe prawoznawstwa, PWN, Warszawa 1980, s. 471; T. Zieliński, Klauzule generalne w prawie pracy, PWN, Warszawa 1988, s. 35-41; L. Leszczyński, op. cit., s. 77-83.

${ }_{14}$ W. Lang, System prawny i porzadek prawny, w: O. Bogucki, S. Czepita (red.), System prawny a porzqdek prawny, WN US, Szczecin 2008, s. 13. 
społeczeństwa, a czego wyrazem staje się m.in. określony kształt oficjalnej doktryny moralnej ${ }^{15}$. To właśnie ta kategoria wartości ma swoje stałe miejsce w preambułach konstytucyjnych. Konstytucja RP umieszcza w niej „wartości ogólnoludzkie” oraz „wartości uniwersalne”"16 ze szczególnym uwzględnieniem „prawdy, sprawiedliwości, dobra i piękna”.

Wszystkie trzy klasy wartości prawodawcy pozostają w stosunku do siebie w określonym układzie: wartości obowiązujące prawnie są otoczone pasem wartości odesłania, a te z kolei - pasem wartości uniwersalnych.

Definiując system prawa jako odpowiednio uporządkowany zbiór norm postępowania o określonej charakterystyce, pozostawia się tym samym poza jego zakresem inne - niż normy prawne - elementy, w tym także wartości. Ale obok formalnego ujęcia prawa pod postacia systemu normatywnego możliwe jest skonstruowanie takiego pojęcia porządku prawnego, którego częściami sa zarówno normy prawne, jak i inne kategorie, np. obowiązujące wartości prawne. Wówczas w pełni uzasadnione stają się odwołania polskiego Trybunału Konstytucyjnego do „norm, zasad i wartości konstytucyjnych” jako wzorca poprawności rozstrzygnięć legislacyjnych, gdzie zgodność nie tylko z normami zwykłymi i zasadami, ale również z wartościami stanowi warunek konieczny uznania konstytucyjności danego aktu. Co charakterystyczne, warunek ten w niezmienionej postaci towarzyszy Trybunałowi Konstytucyjnemu w całej jego działalności ${ }^{17}$.

Źródła prawa zarówno swą legitymację aksjologiczna, jak i zestaw wartości podlegających bezpośredniej i pośredniej ochronie poprzez ich konstrukcję, dopuszczalną treść oraz akceptowane koncepcje czerpia przede wszystkim z wartości prawnych.

W swoim podstawowym znaczeniu „źródło prawa” (fons iuris oriundi) odnosi się do faktu społecznego, który ze względu na obowiązująca konstytucję i uzupełniająca ją doktrynę prawniczą kwalifikowany jest jako fakt prawotwórczy ${ }^{18}$. Zupełna teoria źródeł prawa powinna charakteryzować się tym, że na podstawie jej elementów o każdej dowolnej normie postępowania (sformułowanej albo jedynie dającej się sformułować) można z całą pewnością orzec, czy stanowi czy też nie normę obowiązującego systemu prawnego. Nie da się rozstrzygnaćc tej kwestii tylko na podstawie standardowego ujęcia źródeł prawa jako katalogu dopuszczalnych form prawa pisanego

${ }^{15}$ W. Lang, Teoria prawa, Wydawnictwo UMK, Toruń 1972, s. 116, 117, 118. Podobną funkcję pełni dominująca ideologia społeczno-polityczna, a nawet pewne akty o charakterze politycznym. Zob. Z. Ziembiński, Wstep do aksjologii dla prawników, Wydawnictwo Prawnicze, Warszawa 1990, s. 171.

${ }^{16}$ Zob. też: „Krag organizacji i organów międzynarodowych, o których mowa w art. 90 ust. 1 [Konstytucji RP - dop. MK] ograniczony jest także, chociaż nie zostało to wyrażone wprost, przez to, że daną »organizację« lub "organ" musi łączyć z Polską wspólny system wartości uniwersalnych [podkr. - MK], takich jak demokratyczny ustrój, przestrzeganie praw człowieka", w: K. Działocha, Komentarz do art. 90 Konstytucji RP, w: L. Garlicki (red.), Konstytucja Rzeczypospolitej Polskiej. Komentarz, t. 1, Wyd. Sejmowe, Warszawa 1999, cz. III, s. 5.

${ }^{17}$ Charakterystyczna fraza występuje zarówno np. w orzeczeniu TK z 4 października $1995 \mathrm{r}$. (K. 8/95), OTK 1995, cz. II, poz. 28, s. 33, jak i w wyroku TK z 4 listopada 2015 r. (K 1/14), OTK ZU 2015, seria A, poz. 163, s. 2151.

${ }^{18}$ Z. Ziembiński, Teoria prawa, wyd. 4, PWN, Warszawa-Poznań 1978, s. 79. 
i niepisanego. Stąd konieczność skonstruowania tzw. rozwiniętej normatywnej koncepcji źródeł prawa ${ }^{19}$, w sposób kompletny wyznaczającej drogę stwierdzania prawnego obowiązywania określonych norm (a nie jedynie aktów normatywnych rozpatrywanych jako wytwór czynności prawotwórczych określonego rodzaju ${ }^{20}$ ).

Koncepcja ta jako niezbędne składniki wymienia: 1) uzasadnienie polityczne podstaw systemu prawnego; 2) kompetencje normodawcze organów władzy publicznej; 3) prawotwórczą rolę zwyczaju i precedensów; 4) dopuszczane $\mathrm{w}$ danym systemie reguły interpretacyjne; 5) dopuszczane w danym systemie reguły inferencyjne oraz 6) dopuszczane w danym systemie reguły kolizyjne.

Dopiero wzięcie pod uwagę wszystkich tych elementów pozwala zarówno na uznanie danego faktu za prawotwórczy przez zastosowanie przyjmowanych reguł walidacyjnych, jak i na związanie z tym faktem obowiązywania normy o wyznaczonym kształcie w wyniku odwołania się do akceptowanych reguł interpretacyjnych (językowych, funkcjonalnych, systemowych) lub inferencyjnych (reguł tzw. wnioskowań prawniczych). Ostatecznie reguły kolizyjne pozwalają na wyeliminowanie z systemu prawnego - a ściślej mówiąc, z jego części, w skład której wchodzi badana norma - niedających się znieść w inny sposób niezgodności (sprzeczności, przeciwieństwa norm) między normą badaną a inną normą tak, by wykazać, że normą nieobowiąującą (gdyż zakwalifikowana jako lex prior, lex generalis czy lex inferior) nie jest norma badana.

Pierwsza grupa wartości budujących aksjologię źródeł prawa wywodzi się zarówno z wartości powszechnie uznawanych za wiążące, jak i z wartości prawnych, w szczególności konstytucyjnych. To co dla nich charakterystyczne, to fakt, że wszystkie one mają swoje trwałe miejsce w leżących u podstaw obowiąującego systemu prawnego określonych doktrynach politycznych ${ }^{21}$, będących teoretycznym wyrazem ukształtowanego porządku politycznego ujmowanego jako takie ułożenie stosunków w państwie, które odpowiada właśnie owym wartościom. Początkowo występujące jako hasła polityczne, ostatecznie wartości te zostały zinternalizowane normatywnie i przyjęły postać przede wszystkim naczelnych zasad ustrojowych. System władzy suwerena podporządkowano wartości demokracji, system rządów - wartości podziału władzy, wartość państwa prawnego zyskała miano naczelnej w odniesieniu do systemu prawa, podobną rolę pełnią wartość konstytucjonalizmu w systemie praw jednostki oraz wartość sprawiedliwości społecznej w systemie społecznym ${ }^{22}$. Refleks tej ostatniej wartości można znaleźć w wartości naczelnej systemu gospodarczego - społecznej gospodarce rynkowej ${ }^{23}$. Wyraźnie powiązane z wykonywaniem władzy publicznej wartości te zostają zwieńczone - z jednej strony

19 Ibidem, s. 80.

20 S. Wronkowska, O źródtach prawa i aktach normatywnych raz jeszcze, w: A. Nowicka (red.), Prawo prywatne czasu przemian. Księga pamiatkowa dedykowana Profesorowi Stanistawowi Sottysińskiemu, Poznań 2005, s. 114.

${ }^{21}$ Nadających kształt „ideom ogólnym nowożytnego konstytucjonalizmu, które w europejskiej tradycji są miarą jego podstawowych i uniwersalnych wartości”, w: A. Pułł, Idee ogólne a zasady prawa konstytucyjnego, „Państwo i Prawo” 1995, z. 8, s. 23.

${ }^{22}$ A. Pułło, Idee ogólne..., s. 23; idem, Sprawiedliwość społeczna w systemie zasad naczelnych Konstytucji RP, „Państwo i Prawo” 2003, z. 7, s. 5.

${ }^{23}$ L. Garlicki, op. cit., s. 75-78. 
- wartościami suwerenności narodu oraz niepodległości i suwerenności państwa $^{24}$, z drugiej zaś - klasycznymi wartościami moralnymi przekształconymi decyzją ustrojodawcy w wartości prawne: sprawiedliwością dobrem wspólnym, godnością człowieka, solidarnością i pomocniczością ${ }^{25}$.

Mimo że spośród powyższych wartości to państwo prawne będzie miało największy wpływ na kształt systemu źródeł prawa rozumianych formalnie, pozostałe wartości nie tworza jedynie swoistego tła aksjologicznego. Zasady suwerenności narodu i demokratyczności przesądzają o szczególnej roli ustawy, zasada podziału władzy leży u podstaw rozdzielenia materii między poszczególne typy aktów normatywnych, zasada konstytucjonalizmu zaś wraz z wartościa godności człowieka zapewnia minimum gwarancji dla pozycji prawnej jednostki w państwie, wykluczając pewne sfery z oddziaływań innych niż ustawodawcze, determinowanych ponadto określonym konstytucyjnie katalogiem warunków.

Drugi składnik rozwiniętej normatywnej koncepcji źródeł prawa - kompetencje normodawcze organów władzy publicznej - konstrukcję swojej aksjologii opiera na szczególnym złożeniu wartości formalnych i materialnych. Przy czym to wartości formalne tworza właściwy budulec, wartości materialne zaś pełnia funkcję legitymizująca. Jednakże bez tego treściowego usprawiedliwienia żaden element systemu wartości źródeł prawa nie zyskałby statusu obowiązującego.

Swoista metawartością dla kwestii źródeł prawa jest ich racjonalizacja ${ }^{26}$. Dotyczy to zarówno samego procesu prawotwórczego, jak i katalogu aktów normatywnych będących efektem tego procesu oraz podmiotów wyposażonych w kompetencje prawodawcze. Realizacja tej wartości stała się konstytucjonalizacja podstawowych rozstrzygnięć tego porządku. Polska ustawa zasadnicza z $1997 \mathrm{r}$. po raz pierwszy zagadnieniom źródeł prawa poświęciła odrębny rozdział.

Zagwarantowanie na poziomie konstytucyjnym określonego kształtu systemu źródeł prawa służy nie tylko pewności prawa oraz bezpieczeństwu prawnemu rozpatrywanym jako wartości formułowane w stosunku do systemu prawa z perspektywy Hartowskiego zewnętrznego obserwatora ${ }^{27}$, ale nadto sprzyja stałości prawa oraz poczuciu bezpieczeństwa prawnego jednostek i innych adresatów norm prawnych ${ }^{28}$, a więc dotyczy samego prawa i jego działania. Wszystkie te cztery aspekty pewności tworzą istotę formalnego ujęcia państwa prawnego.

Także ukształtowana już koncepcja państwa prawnego przesądziła o przyjęciu przez polskiego ustrojodawcę zasady hierarchicznej budowy systemu źródeł prawa oraz przyznaniu aktom pochodzacym od parlamentu jako podmiotu reprezentującego suwerena - konstytucji i ustawom - mocy prawnej sytuującej je na szczycie tej hierarchii ${ }^{29}$. Wartość hierarchiczności systemu

${ }^{24}$ Ibidem, s. 52-57.

${ }^{25}$ A. Pułło, Sprawiedliwość..., s. 11. O możliwości systemowego uporządkowania owych wartości zob. też: M. Kordela, Zasady prawa..., s. 152-156.

${ }^{26}$ J. Wróblewski, System źródeł prawa w Konstytucji PRL, w: A. Patrzałka (red.), Problemy prawodawstwa w nowej konstytucji PRL, Wyd. UWr, Wrocław 1988, s. 40.

${ }^{27}$ H. L. A. Hart, The Concept of Law, 2nd ed., Clarendon Press, Oxford 1994, s. 57.

28 J. Wróblewski, System..., s. 39-40.

${ }^{29}$ L. Garlicki, op. cit., s. 63, 120. 
źródeł prawa ma charakter wartości zbiorczej, a jej konieczne składniki to, po pierwsze, wymóg stanowienia norm o niższej mocy prawnej na podstawie wyraźnego upoważnienia zawartego w normach o mocy wyższej (aspekt podstawy kompetencyjnej), po drugie, wymóg zgodności treściowej norm niższego rzędu z normami rzędu wyższego (aspekt merytoryczny), po trzecie, wymóg uchylania i zmiany norm danego szczebla przez normy szczebla równorzędnego lub wyższego (aspekt derogacyjny) i ostatecznie, po czwarte, wymóg poszanowania wyznaczonych zakresów regulacyjnych - np. poprzez koncepcję tzw. wyłączności ustawy (aspekt zakresu kompetencji) ${ }^{30}$.

Konsekwentnie zasadzie hierarchiczności zostały podporządkowane akty prawa powszechnie obowiązującego. Leżący u podstaw tej kategorii podział źródeł prawa na powszechnie obowiązujace i mające charakter wewnętrzny pełni fundamentalną rolę zarówno w konstrukcji jasnego i przejrzystego katalogu aktów normatywnych (a co najmniej ich generalnych zbiorów), jak i w zabezpieczaniu praw jednostki. Zgodnie z przyjętym kryterium podziału jedynie normy powszechnie obowiązujące mogą być adresowane do wszystkich podmiotów podległych danemu systemowi prawnemu, w szczególności do obywateli, osób prawnych prawa prywatnego, ale także do stowarzyszeń, organizacji, partii politycznych oraz do organów i instytucji władzy publicznej. Tylko akt normatywny tego typu jest władny wyznaczać sytuacje prawna jednostce i może „stanowić podstawę decyzji wobec obywateli, osób prawnych i innych podmiotów” (art. 93 ust. 2 zd. 2 Konstytucji RP). Z kolei akty o charakterze wewnętrznym „obowiązują tylko jednostki organizacyjnie podległe organowi wydającemu te akty” (art. 93 ust. 1 Konstytucji RP) i żadne ich rozstrzygnięcia nie moga wpływać na sytuację prawną jednostek spoza „organizacyjnej podległości”.

Gwarancyjna rola aktów powszechnie obowiąujących została zabezpieczona przez ustrojodawcę zamknięciem na poziomie centralnym - zarówno w aspekcie przedmiotowym, jak i podmiotowym - ich systemu. To sama konstytucja enumeratywnie wylicza wszystkie formy aktów tej kategorii oraz wszystkie podmioty wyposażone w kompetencje do ich stanowienia.

Normami o najwyższej mocy prawnej są normy konstytucji. Zasada jej nadrzędności i odpowiadająca tej zasadzie wartość działa we wszystkich czterech wyróżnionych aspektach hierarchiczności nie tylko w odniesieniu do norm prawa krajowego, ale także do włączonych do polskiego porządku prawnego norm prawa międzynarodowego publicznego oraz prawa unijnego. Co więcej, w przypadku wyodrębniania podsystemów (gałęzi) systemu źródeł prawa każda $\mathrm{z}$ tych autonomicznych całości jest bezpośrednio podporządkowana ustawie zasadniczej ${ }^{31}$. Nadrzędność konstytucji w systemie źródeł prawa zabezpieczaja przede wszystkim dwa mechanizmy: mechanizm instytucjonalny - pod postacią kontroli konstytucyjności i legalności aktów normatywnych, ze szczególną

${ }^{30}$ Ibidem, op. cit., s. 127-128; K. Płeszka, Hierarchia w systemie prawa, Wyd. UJ, Kraków 1988, s. 119-132; S. Wronkowska, Podstawowe pojęcia prawa i prawoznawstwa, wyd. 2 , Ars boni et aequi, Poznań 2003, s. 46-47.

${ }^{31}$ P. Sarnecki, Konstytucyjny system źródet prawa o charakterze powszechnym, w: E. Gdulewicz, H. Zięba-Załucka (red.), Dziesięć lat Konstytucji Rzeczypospolitej Polskiej, Wyd. UR, Rzeszów 2007, s. 257. 
rolą Trybunału Konstytucyjnego ${ }^{32}$ oraz mechanizm zamykający (domykający) system aktów stosowania prawa. Oto w przypadku braku normatywnej podstawy rozstrzygnięcia albo w sytuacji jej niezgodności z konstytucją na podstawie ust. 2 art. 8 Konstytucji RP podmiot stosujący prawo, np. sąd, ma kompetencje do bezpośredniego zastosowania normy konstytucyjnej ${ }^{33}$.

Normami usytuowanymi na poziomie bezpośrednio następującym po konstytucji są normy umów międzynarodowych, ratyfikowanych albo w trybie art. 89 ust. 1 (na podstawie uprzedniej zgody wyrażonej w ustawie), albo w trybie art. 90 ust. 2-4 Konstytucji RP (normy umów międzynarodowych przekazujących organizacji międzynarodowej lub organowi międzynarodowemu kompetencje organów władzy państwowej w niektórych sprawach). Na tym samym szczeblu znajduja się także normy unijnego prawa pochodnego. Bezpośrednio podkonstytucyjna ranga tych norm podkreśla wagę, jaką ustrojodawca polski przywiązuje do pozycji państwa w porządku międzynarodowym i ponadnarodowym.

Kolejny szczebel tworzą normy ustaw jako aktów pochodzących wyłącznie od parlamentu. Wartościa dlań konstytutywna jest zasada zwierzchnictwa ustawy. Oznacza to, że każdy akt prawodawczy pochodzacy od organów władzy wykonawczej musi być jej podporządkowany, tzn. że może być wydany jedynie na podstawie szczegółowego upoważnienia zawartego w ustawie i w celu jej wykonania. „Bez wyraźnego przyzwolenia ustawy w systemie prawa krajowego nie może się więc znaleźć jakakolwiek norma powszechnie obowiązującego prawa, co jest jedna z najistotniejszych zmian wprowadzonych przez nowa konstytucje" ${ }^{34}$. Właśnie to stanowisko ustrojodawcy spowodowało, że zasada zupełności koniecznego zakresu ustawy ${ }^{35}$ zasadę ustawy ${ }^{36}$ wyłączności zastąpiła jako wskazująca na określone sfery, do normowania których kompetencje posiadał jedynie ustawodawca. Konstytucja RP z 1997 r. przesądziła o tym, że nie ma już pewnych obszarów zastrzeżonych dla ustawy - cała obszar regulacyjny należy do niej. Ustawa swoją pozycję dodatkowo wzmacnia zasadą nieograniczoności przedmiotowej. Każda materia ${ }^{37}$ może stać się obiektem regulacji ustawowej, jeżeli zapadnie taka decyzja polityczna.

Moc prawna równą ustawom maja rozporządzenia z moca ustawy, do wydawania których kompetencje uzyskał prezydent. Rola tych aktów normatywnych jest jednak wyraźnie ograniczona. Moga być stanowione jedynie na wniosek Rady Ministrów oraz po uzyskaniu kontrasygnaty premiera i tylko wtedy, gdy zostanie wprowadzony stan wojenny, a Sejm nie może zebrać się

32 O relacji między zwiększającym się ugruntowaniem zasady nadrzędności konstytucji a rolą sądu konstytucyjnego - zob. R. M. Małajny, Legitymacja sqdownictwa konstytucyjnego, „Państwo i Prawo" 2015, z. 10, s. 21.

${ }^{33} \mathrm{O}$ szczególnej roli tego mechanizmu - zob. w szczególności M. Safjan, Polityka a Trybunat Konstytucyjny. Konstytucja - ostatni środek obrony przed polityka, „Ruch Prawniczy, Ekonomiczny i Socjologiczny” 78, 2016, z. 1, s. 40-42.

${ }^{34}$ L. Garlicki, op. cit., s. 131.

35 Ibidem, s. 133.

36 A. Krzywoń, Podstawowe założenia systemu źródeł prawa PRL a postepowanie wywłaszczeniowe, „Przegląd Legislacyjny” 2015, nr 4, s. 11-14.

37 Jedynymi ograniczeniami dla regulacji ustawowej sa normy konstytucji, umów międzynarodowych ratyfikowanych za uprzednią zgodą wyrażoną w ustawie oraz normy regulaminów Sejmu i Senatu, a także regulaminu Zgromadzenia Narodowego. 
na posiedzenie. Zakres normowania rozporządzeń z mocą ustawy został podporządkowany wymogom wprost sformułowanym przez Konstytucję, a nadto muszą być one zatwierdzone przez Sejm na najbliższym posiedzeniu. Wyjątkowy charakter tych aktów powoduje, że to ustawy mają monopol regulacyjny na tym szczeblu.

Normy powszechnie obowiązujące kolejnego szczebla to wydawane na poziomie centralnym akty wykonawcze do ustaw przyjmujace formę rozporządzeń. Ich ścisłe powiązanie z ustawami wynika, z jednej strony, z zasady zupełności ustawy, z drugiej zaś - z konstrukcji konstytucyjnej tego rodzaju aktu prawodawczego. Rozporządzenia mogą być wydawane jedynie na podstawie szczegółowego upoważnienia zawartego w ustawie i w celu jej wykonania. To sam ustawodawca podejmuje decyzję, czy i w jakim zakresie przekazać podmiotom władzy wykonawczej określoną materię do uregulowania. Jeżeli takie rozstrzygnięcie zapadnie, to norma kompetencji prawodawczej winna zostać zbudowana według precyzyjnego wzorca sformułowanego przez ustrojodawcę: musi szczegółowo określić podmiot zyskujący kompetencję do wydania rozporządzenia, przy czym podmiot ten winien mieścić się w konstytucyjnym zamkniętym katalogu upoważnionych do dokonywania tego typu czynności konwencjonalnych (szczegółowość podmiotowa), następnie musi szczegółowo wyznaczyć zarówno zakres regulowanej materii (szczegółowość przedmiotowa), jak i wytyczne dotyczące treści aktu (szczegółowość treściowa). Tylko rozporządzenie wylegitymowane spełniającym konstytucyjne warunki upoważnieniem ustawowym, niewykraczające poza wskazany zakres, realizujace cel ustawy macierzystej oraz niesprzeczne zarówno z konstytucja, jak i z każdym - a więc nie tylko upoważniającym - aktem ustawodawczym zostanie uznane za poprawny składnik systemu źródeł prawa. Restrykcyjność koncepcji rozporządzenia jako aktu wykonawczego podkreśla wyraźne sformułowanie zakazu stanowienia rozporządzeń samoistnych oraz zakazu domniemania kompetencji prawotwórczej, a także zakaz subdelegacji.

Jasność i precyzja prawnego charakteru rozporządzeń oraz uczynienie z nich jedynej kategorii aktów wykonawczych ${ }^{38}$ spowodowały powstanie instytucji jednorodnej, dzięki której została zrealizowana - co najmniej w pewnym zakresie - formalna wartość jednolitości systemu źródeł prawa, zdecydowanie ograniczająca możliwość naruszeń zasady państwa prawnego przede wszystkim w porządku praw i wolności jednostki, ale także w znacznym stopniu zwiększająca sprawność funkcjonowania państwa ${ }^{39}$.

Normy prawa powszechnie obowiązującego stanowione są także na szczeblu terenowym i przybierają kształt aktów prawa miejscowego. Wydawane przez organy samorządu terytorialnego oraz terenowe organy administracji rządowej obowiązują na obszarze ich działania. Ustrojodawca, szanując wartości autonomiczności oraz swobody organów lokalnych, przyjął, że prawo

\footnotetext{
${ }^{38}$ Zgodnie z przyjętym stanowiskiem doktryny - zob. A. Preisner, Zakres i formy prawotwórczej działalności organów wykonawczych, w: E. Zwierzchowski (red.), Prawo i kontrola jego zgodności z Konstytucja, Wyd. Sejmowe, Warszawa 1997, s. 48.

${ }^{39}$ S. Wronkowska, Źródta prawa w projekcie konstytucji Komisji Konstytucyjnej Zgromadzenia Narodowego, „Przegląd Legislacyjny” 1996, nr 4, s. 36; K. Działocha, Komentarz do art. 87, w: L. Garlicki (red.), op. cit., s. 7.
} 
miejscowe może być tworzone na podstawie i w granicach upoważnień zawartych w ustawie, a więc po spełnieniu warunków mniej restrykcyjnych niż te, które zostały nałożone na rozporządzenia (szczegółowe upoważnienie i wydanie w celu wykonania ustawy).

Wszystkie kategorie powszechnie obowiązujących źródeł prawa - zarówno na szczeblu centralnym, jak i lokalnym - podlegaja ogłoszeniu. Jest to nie tylko warunek konieczny ich wejścia w życie, ale nadto podstawowa składowa aksjologii źródeł prawa: dzięki tej wysoce sformalizowanej czynności konwencjonalnej powstaje stan pewności zarówno co do zaistnienia faktu prawotwórczego, jak i kształtu jego efektu - określonego aktu normatywnego. Jawność podanego w ten sposób do wiadomości publicznej prawa staje się tym samym istotnym usprawiedliwieniem dla wiązania zasady ignorantia iuris nocet ${ }^{40}$, a prawodawca tym samym realizuje wartość wyrażoną w jednej z fundamentalnych zasad państwa prawnego: zasadzie zaufania obywateli do państwa i stanowionego przez nie prawa.

Wprawdzie druga kategoria dualnego podziału źródeł prawa - akty o charakterze wewnętrznym - nie została zbudowana ani na zasadzie hierarchiczności, ani zgodnie z wymogami zamknięcia podmiotowego i przedmiotowego, to ustrojodawca nie nadał jej zupełnie autonomicznego charakteru. Akty te bowiem moga być wydawane tylko na podstawie ustawy i muszą być zgodne z prawem powszechnie obowiąującym. Dzięki obu tym warunkom spójność koncepcji źródeł prawa - co najmniej na najogólniejszym poziomie konstrukcyjnym - zostaje zachowana.

Rozwinięta normatywna koncepcja źródeł prawa w postaci swego trzeciego składnika wymaga zajęcia stanowiska co do prawotwórczej roli zwyczaju i precedensu. Ze względu na przyjętą w polskiej doktrynie prawa konstytucyjnego taką interpretację zasady podziału władzy, jaka wyklucza przyznanie kompetencji prawodawczych podmiotom, których podstawowa funkcja polega na stosowaniu prawa, precedens jako fakt prawotwórczy nie może zostać zaakceptowany. Natomiast zgodnie z art. 9 Konstytucji RP Rzeczpospolita Polska przestrzega wiążącego ja prawa międzynarodowego, a więc w polskim porządku prawnym obowiązują normy o charakterze zwyczajowym jako jedno z podstawowych źródeł prawa międzynarodowego. Wydaje się także, że kształtowanie się prawa zwyczajowego w porządku krajowych źródeł prawa nie jest wykluczone, na co wskazuje w niczym niezanegowana przez współczesnego ustrojodawcę tradycja polskiego systemu prawnego ${ }^{41}$.

Ostatnie trzy elementy składowe przywoływanej teorii - reguły interpretacyjne, reguły inferencyjne oraz reguły kolizyjne tworzace jako całość reguły egzegezy tekstu prawnego - jakkolwiek w nauce prawa konstytucyjnego niewiążące się bezpośrednio z kategorią fontes iuris oriundi, odgrywają kluczową rolę w zagwarantowaniu wartości pewności w sposób konieczny wiązanej z ujęciem źródeł prawa. Dzieje się tak dlatego, że system prawny w podstawowym tego słowa znaczeniu zbudowany jest nie z przepisów prawnych czy

40 S. Wronkowska, Podstawowe pojęcia..., s. 123; P. Winczorek, Komentarz do Konstytucji Rzeczypospolitej Polskiej z dnia 2 kwietnia 1997 r., Liber, Warszawa 2000, s. 112.

41 S. Wronkowska, O źródtach prawa..., s. 118-119. 
aktów normatywnych, ale z norm prawnych, które wymagają wyinterpretowania, wyinferowania oraz uporządkowania. Bez tych trzech typów czynności egzegetycznych „źródła prawa” miałyby charakter dosłowny: oznaczałyby jedynie swoisty początek prawa, ale już nie jego właściwą postać, tzn. taka, jaka pozwala na precyzyjne określenie tego, kto, w jakich okolicznościach i w jaki sposób powinien postapićc ${ }^{42}$.

Poruszając się pomiędzy wartością bezpieczeństwa prawnego preferowana przez statyczne teorie wykładni a wartościa „adekwatności prawa i życia”, leżącą u podstaw teorii dynamicznych ${ }^{43}$, interpretator, posługując się dyrektywami językowymi, funkcjonalnymi oraz systemowymi z przepisów aktów normatywnych - rezultatów czynności stanowienia - odkodowuje jednoznaczne normy postępowania znajdujace należyte uzasadnienie aksjologiczne w ocenach przypisywanych racjonalnemu prawodawcy oraz niepozostajace w relacji niezgodności z jakąkolwiek inną normą systemu. Ale według założenia racjonalności prakseologicznej prawodawcy do systemu prawa należą nie tylko normy wprost wyrażone w tekście prawnym, ale także te, jakie można z nich wyprowadzić na podstawie przyjętych wnioskowań prawniczych ${ }^{44}$. Prawodawca bowiem, „chcac”, by obowiązywały dane normy, „chce” tym samym - jako podmiot konsekwentny - aby obowiązywały normy, których realizacja jest warunkiem koniecznym realizacji tych pierwszych, czy też takie, jakie znajduja uzasadnienie aksjologiczne w takich samych ocenach, jak oceny legitymujace te pierwsze. Mnogość norm wyinterpretowanych i wyinferowanych pociaga za sobą nieuchronne ich konflikty. Eliminowanie niezgodności jest ostatecznie domeną reguł kolizyjnych ${ }^{45}$.

Jeżeli doktryna prawa danego kraju co do każdego z sześciu składników rozwiniętej normatywnej koncepcji źródeł prawa ma wypracowane wyraźne i szczegółowe stanowisko, to o faktycznie funkcjonującym systemie źródeł prawa można niezawodnie orzec, że spełnia nie tylko wartości formalne: zupełność, spójność, całościowość, przejrzystość konstrukcji, a tym samym pewność i przewidywalność działań prawodawczych, ale nadto pełni funkcję niezawodnego gwaranta wartości materialnych: ochrony praw i wolności jednostki, skutecznej realizacji dobra wspólnego i przyjętych formuł sprawiedliwości społecznej, prawidłowego działania zasady podziału władzy.

Polska nauka prawa, mocno wspierana działalnością orzecznicza, osiagnięcie tego stanu rzeczy uznaje za swą elementarną powinność. Nie zawsze dającą się realizować w jednakowo wysokim stopniu.

dr hab. Marzena Kordela

Profesor Uniwersytetu im. Adama Mickiewicza w Poznaniu

kordela@amu.edu.pl

\footnotetext{
${ }^{42}$ M. Zieliński, Wyktadnia prawa. Zasady, reguły, wskazówki, wyd. 5, LexisNexis, Warszawa 2010, s. 17-18.

${ }^{43}$ J. Wróblewski, Zagadnienia teorii wyktadni prawa ludowego, Wydawnictwo Prawnicze, Warszawa 1959, s. 159-175.

${ }^{44}$ Z. Ziembiński, Problemy podstawowe prawoznawstwa, PWN, Warszawa 1980, s. 299-304.

${ }_{45}$ Ibidem, s. 304-309.
} 


\section{AXIOLOGY OF THE SOURCES OF LAW}

Sum mary

The expression 'sources of law' (fontes iuris oriundi) denotes a social fact which due to the constitution and legal doctrine is qualified as a law-making fact. A complete theory of the sources of law ought to be such that based on its elements it should be possible to state unequivocally whether a given norm of conduct does or does not belong to the norms of the legal system that is binding and applicable. This, in turn, may be decided base on a so-called extended normative conception of the sources of law.

The necessary components of this conception are: (i) the political justification of the foundations of a legal system; (ii) the law-making competences of the organs of public authority; (iii) the law-making role of the custom and precedent; (iv) the law-interpreting rules permitted in a given system; (v) the interference rules permitted in a given system, and (vi) the rules governing the conflict of laws in a given system.

The system of the sources of law created in this way is on the one hand legitimised by certain values while on the other hand it implements many of them in practice. The basic part of the axiology of the legislator in the sphere of the sources of law is made up by the legally binding values, i.e. the values which the legislator himself introduced to the legal system. They include first and foremost the rule of law, the certainty of law and the citizens' confidence in the state and the laws made by the state as well as the dignity of a human being and the rights and freedoms of an individual. Apart from the legal values there are values of universal character upon which political doctrines are built. These too influence the shape of the sources of law. 